\title{
Growth Performance of Rice in Green Revolution Belt of India: A Spatio-Temporal Analysis
}

\author{
Arghyadeep Das ${ }^{1}$ and Sanjay Kumar ${ }^{2}$ \\ ${ }^{1}$ Division of Economics Statistics and Management, NDRI, Karnal- 132001, Haryana, India \\ ${ }^{2}$ Senior Agricultural Economist, Punjab Agricultural University, Ludhiana- 141004, Punjab, India \\ "Corresponding author: dasarghyadeep198@gmail.com
}

\begin{abstract}
The present study was conducted to analyze the rice cultivation scenario in Punjab from 1994-95 to 201516. The study was based on secondary data collected from various sources. Study showed that growth rate of area, production, yield, area under HYV and irrigation was much higher in period I (1994-04) than in period II (2004-16). Among the districts Sangrur had the highest growth rate in yield and in terms of area and production Muktsar had highest growth rate in overall studied period i.e. period III (1994-16). Sangrur and Amritsar was among the top three districts in terms of both area under rice cultivation and production. The coefficient of variable GCA had positive and significant effect on growth of area, production and yield. Rainfall (R) and literacy rate (LR) had positive and significant effect in growth of area. Fertilizer consumption (FC) had negative and significant effect in terms of growth of area and positive and significant effect in terms of growth of yield.

\section{Highlights}

( Area, production, yield of rice and irrigated land showed significant positive growth rate throughout the study period.

(0 District wise also same scenario is observed.

0 Sangrur district had highest growth rate in terms of area and production.

$\boldsymbol{0}$ Gross cultivable area is the only variable which is positively effecting area, production and yield of rice.
\end{abstract}

Keywords: Green Revolution, Punjab, rice, area, production, Productivity

Rice occupies about $24 \%$ of total cropped area of the country. Rice is the major component of food grain and cereal in the country contributes $43 \%$ and $46 \%$ of the total food grain and cereals respectively. India accounts for $22 \%$ of total world's rice production. In Eastern and southern part of the country rice is considered as staple food. Most outstanding states in India for the production of rice were West Bengal (13.91 \%), Andhra Pradesh (6.85\%), Uttar Pradesh (11.53\%), Punjab (10.53\%), Odisha (7.87 \%), Tamil Nadu (5.43 \%), Chhattisgarh (5.99\%), Bihar (6.02\%), Karnataka (3.36 \%) and Haryana (3.80 \%) during the period 2014-15 (Anonymous, 2016). The area under rice was found to be 44 million hectares in 201415 crop year occupying about 24 percent of total cropped area of the country. Due to severe drought
India's rice production declined from record 99.18 million tonnes in the year 2008-09 to 89.13 million tonnes during 2009-10 but again gained its momentum and reached to a record high of 104.4 MT during the period 2015-16 (Anonymous, 2016).

The objectives of the "Green Revolution" were to: (1) make available the required inputs in sufficient quantities; (2) encourage investment in fertilizer factories and the manufacturing of agricultural equipment; (3) identify and coordinate agricultural research activities to raise productivity; (4) intensify agricultural extension service in selected areas; (5) provide adequate credit to the farmers who are willing to grow varieties of cereals and adopt the appropriate farm practices; and (6) implement a production-oriented cereal price policy (Rena and 
Ravinder, 2004). During Green Revolution Period, there was a continuous surge for diversifying agriculture in terms of crops, primarily on economic considerations (Joshi et al. 2006; Paltasingh and Goyari, 2013) After the introduction of the Green Revolution in the late 1960s and 1970s, Punjab experienced a remarkable agricultural growth. It had improved the general socio-economic condition of the farmers and catapulted it to the status of being called the 'grain bowl of India' or the 'bread basket of India'. Since then, the agricultural production sectors in Punjab have become highly capital intensive and mechanized (Dutta, 2012). A tremendous progress can be seen in rice production in Punjab although it was not a traditional rice growing state. This notable growth in agricultural production in this state was due to the blessing of green revolution which bought a optimum mix of technological and institutional factors. Punjab is responsible to hand out $13-14 \%$ of total country's food grain production although it constitutes only $1.54 \%$ of the total country's geographical area. Contribution of $35-40 \%$ of rice and $40-75 \%$ of wheat to the central pool in past two decades had resulted to earn the name as granary of India by this state. In the wake of new technology, Punjab's agriculture had made rapid progress since mid sixties. Rapid adoption of improved seeds, irrigation and speedy use of non-conventional inputs like pesticides, machinery, fertilizers had made the progress of Punjab possible. The sustainability of green revolution persists till eighties after that state's agricultural production had showed sign of stagnation. Rising cost of cultivation of major crops further added fuel to this situation and compressed the profitability of agriculture adversely affecting the standard of living of farmers of the state.

It is needless to say that a momentous changes in the cropping pattern of Punjab had been brought by green revolution. Area coverage under rice increased from only $6.87 \%$ of gross cropped area in $1970-71$ to $33.15 \%$ in $2007-08$ and further increased to $34.30 \%$ in $2014-15$ (Anonymous 2016). Although Punjab consists of $6.60 \%$ of total rice growing area of the country, it is also responsible for $10.60 \%$ of total country's rice production and the state with highest rice productivity of $3838 \mathrm{~kg}$ per hectare (Anonymous, 2015). Agriculture in Punjab is the means of livelihood of about $62.5 \%$ of total population are rural population. The significance of agriculture to state's economy can be judged from its contribution of $17.03 \%$ to the Gross State Domestic Product in 2015-16 at 2011-12 prices (Anonymous, 2016). The state's net sown area is $82 \%$ of total geographical area which is almost double of national average $(46 \%)$. Presently the gross cropped area of the state is 7728.2 thousand hectares with cropping intensity of $185 \%$ with $99 \%$ area under irrigation (Anonymous, 2016). In Punjab, the area and production under food grains during 2014-15 were 6549 thousand hectare and 26703 TMT respectively, out of which rice alone covered $44.1 \%$ in the case of area and $41.7 \%$ in case of production (Anonymous, 2015).

\section{MATERIAL AND METHODS}

The green revolution belt of India primarily constitute Punjab, Haryana and Western Uttar Pradesh. Out of the 3 states, Punjab was chosen randomly for the macro framework based study on secondary data. The objective of this study is to analyse the historical pattern in the growth of agricultural production and productivity in Punjab and suggest a perspective for its development. A look into the growth pattern of area, production and productivity of major crop groups is indeed an essential prerequisite. I may be pertinent to note that although some studies have been carried out in other agarian states of the country (Bhalla and Singh, 2009; Bhattacharyaand Bhattacharya, 2007; Vakulbharanam, 2004; Subrahmanyam and Satya Sekhar, 2003) but a comprehensive study in green revolution belt is seldom found. To meet the objectives of this study, data on different variables such as area, production and yield of rice of selected two states were collected from India stat.com and statistical abstracts of the respective states.

Compound Annual Growth Rate (CAGR) of area, production and productivity were worked out to evaluate the performance of rice crop district wise for both states. The period was divided into three parts period I (1994-04) period II (2004-16) and overall period i.e period III (1994-16). Period I was broadly corresponded to the period of turbulence in the economy characterized by dwindling of public expenditure in agriculture. Period II was characterized by sharp reversal of the public investment and agricultural performance. 


\section{Merging of districts}

For feasible comparison it was necessary to merge some districts to its parent districts for both states. Merging was based on the ratio of net sown area which were extracted from its parent districts and depicted in the following table as following coefficients:

\begin{tabular}{cccc}
\hline S1. No. & New districts & $\begin{array}{c}\text { Old } \\
\text { districts }\end{array}$ & $\begin{array}{c}\text { Coefficient of merging } \\
\text { of new districts with } \\
\text { its parent districts }\end{array}$ \\
\hline 1 & Taran Taran & Amritsar & 1.00 \\
2 & S A S Nagar & Roopnagar & 0.58 \\
& & Patiala & 0.42 \\
3 & Barnala & Sangrur & 1.00 \\
4 & Fazilka & Firozpur & 1.00 \\
5 & Pathankot & Gurdaspur & 1.00 \\
\hline
\end{tabular}

\section{Growth analysis}

The compound annual growth rates (CAGR's) of area, production, yield, partial factor productivity and total factor productivity of rice and its input growth pattern were estimated for West Bengal and Punjab states by using semi log form of the exponential growth function.

The growth model used is as under:

$$
Y_{\mathrm{t}}=A B^{\mathrm{t}}
$$

Where,

$Y_{t}=$ Area/production/productivity of rice for the year ' $t$ '.

$\mathrm{t}=$ Time variable $(1,2 \ldots \ldots, \mathrm{n})$ for each period.

$\mathrm{A}=$ Constant

$B=$ Growth coefficient

Log transformation of above function is:

$$
\ln Y_{t}=\ln A+t(\ln B) \text {. }
$$

Where,

$$
\begin{aligned}
& \ln B=\ln (1+r), \text { and } \\
& t=[\operatorname{antilog}(\ln B)-1] \\
& C A G R ' s(\%)=[\operatorname{antilog}(\ln B)-1] \times 100
\end{aligned}
$$

Student's-test was used to test the test the significance CAGR.

\section{Determinants of Growth Rate in Area, Production and Yield}

This study has examined the determinants of growth in area, production and yield in rice at

\begin{tabular}{|c|c|c|}
\hline Variables & Notations & $\begin{array}{l}\text { Method of } \\
\text { measurement }\end{array}$ \\
\hline $\begin{array}{l}\text { Growth rates in area, } \\
\text { production and yield }\end{array}$ & $Y$ & $\begin{array}{l}\text { Annual compound } \\
\text { growth rates of area, } \\
\text { production and yield }\end{array}$ \\
\hline Rainfall & $\mathrm{R}$ & $\begin{array}{l}\text { Actual rainfall as } \\
\text { the ratio to normal } \\
\text { rainfall }\end{array}$ \\
\hline Literacy rate & LR & Literacy rate \\
\hline Cropping intensity & CI & $\begin{array}{l}\text { The ratio of gross } \\
\text { cultivable area to net } \\
\text { cropped area }\end{array}$ \\
\hline Gross cultivable area & GCA & $\begin{array}{l}\text { Gross rice cropped } \\
\text { area as a ratio to the } \\
\text { total gross cropped } \\
\text { area }\end{array}$ \\
\hline Gross irrigated area & GIA & $\begin{array}{l}\text { Gross irrigated area } \\
\text { of rice as a ratio of } \\
\text { total gross irrigated } \\
\text { area. }\end{array}$ \\
\hline $\begin{array}{l}\text { Fertilizer } \\
\text { consumption }\end{array}$ & $\mathrm{FC}$ & $\begin{array}{l}\text { Total fertilizer } \\
\text { consumed for crop } \\
\text { production as a ratio } \\
\text { to the gross cropped } \\
\text { area. }\end{array}$ \\
\hline
\end{tabular}
the state level through neo-classical growth model and aggregate growth model can be specified as equation (1):

$$
Y=f(R, L R, C I, G C A, G I A, F C)
$$

The growth rates in area, production and yield generally determine the overall performance of an agarian economy and are treated as dependent variables in a broad analytical framework (Bhattacharya and Bhattacharya, 2007). The consumption of fertilizers and cropping intensity are taken as the main technological variables. The rationale for including rainfall in the production function is that a significant proportion of cultivated area depends on rainfall and its variation affects the crop output substantially. Similarly, as the gross cultivated area had shown very little fluctuation over time, it had been taken as proxy for available land for cultivation. The gross irrigated area represents water-use from all the sources of irrigation for crop production. Education had a significant impact on agricultural productivity through refining the quality of labour, and increasing the access to information and awareness programmes on 
agricultural practices. Thus, literacy rate had been considered as an important variable in the study. Not withstanding the limitations, the selected variables do have a good capacity to present the true picture of overall agricultural performance of the state.

Singh and Singh (1993) studied the growth rates of area, production and productivity of gram in different districts of Bihar; estimated the factors affecting the area, production and productivity of gram. Compound growth rates had been estimated based on the district wise secondary time series data on area, production, productivity, prices, irrigated area, and annual rainfall from 1960-61 to 1989-90. In order to study the impact of various factors on yield a Cobb Douglas type function was fitted using the output per hectare as the dependent variable and annual rain fall, area under irrigation, current year prices $(₹ / q)$ and one year lagged prices $(₹ / q)$ as independent variables.

\section{RESULTS AND DISCUSSION}

Table 1 depicts that during 1994-04 the tremendous increase in rice production of Punjab (3.33 percent) was due to increase in area (2.12 percent) at that time. The similar pattern was followed during 2004-16. But in period-III (1994-16) the growth of production (2.36 percent) was due to both growth in the area (1.29 percent) and yield (1.06 percent). Both the area under HYV and irrigation increased notably during period I, 4.12 and 2.33 percent respectively. In Punjab rice occupied second largest area under cultivation next to wheat, the coverage of land under rice cultivation rose remarkably throughout the period this might be because of effective price policy of the government which was giving the farmers an assured return.

\section{District wise rice cultivation scenario}

The temporal changes of area production and yield across different districts of Punjab is furnished in Table. 2 For the convenience of the study the overall periods have been divided in three parts, Period I (1994-04), Period II (2004-15) and Period III (1994-16).

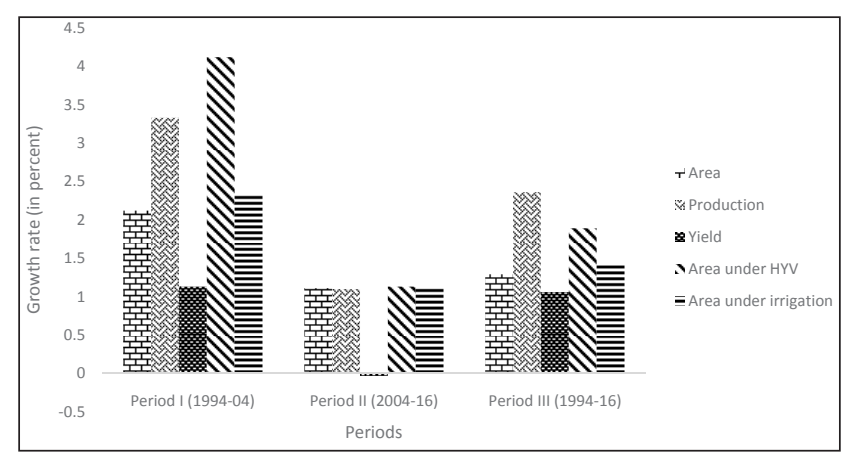

Fig. 1: Compound annual growth rate of area, production, yield, area under HYV and area under irrigation of rice in Punjab

During period I Compound annual growth rate (CAGR) of area, production, yield of Hoshiarpur was stagnant and non significant but during period II production and yield got positive and significant growth rate. Growth rate of production in Gurdaspur was almost same during for both period I and period II but growth rate of yield declined in period II. A sharp increase of CAGR of area and production of Rupnagar in period I became stagnant during period II, although yield improved during Period II but it was still insignificant. S B S Nagar showed a significant growth for area and production for both periods but still growth rate of yield remained insignificant for both periods.

Central plain zone comprised of Rupnagar, Amritsar, Kapurthala, Jalandhar, Ludhiana, Sangrur, Patiala is the main rice producing area for this state. All the districts showed positive growth rate in terms of area, production and yield during Period I except Amritsar, in which CAGR of yield was negative and Jalandhar, in which CAGR of area turned into negative although both of their CAGR

Table 1: Compound annual growth rate of area, production, yield, area under HYV and area under irrigation of rice in Punjab (\% per annum)

\begin{tabular}{cccccc}
\hline Year & Area & Production & Yield & Area under HYV & Area under irrigation \\
\hline Period I (1994-04) & $2.12^{* * *}(0.005)$ & $3.33^{* * *}(0.005)$ & $1.13^{* *}(0.004)$ & $4.12^{* * *}(0.007)$ & $2.33^{* * *}(0.005)$ \\
Period II (2004-16) & $1.11^{* * *}(0.001)$ & $1.10^{* * *}(0.00)$ & $-0.034(0.002)$ & $1.13^{* * *}(0.001)$ & $1.11^{* * *}(0.002)$ \\
Period III (1994-16) & $1.29^{* * *}(0.001)$ & $2.36^{* * *}(0.002)$ & $1.06^{* * *}(0.001)$ & $1.89^{* * *}(0.002)$ & $1.41^{* * *}(0.001)$ \\
\hline
\end{tabular}

Note: ${ }^{* *}$ significant at $1 \%$ level, ${ }^{* *}$ significant at $5 \%$ level, ${ }^{*}$ significant at $10 \%$ level; Figures in the parenthesis are standard errors. 
Growth Performance of Rice in Green Revolution Belt of India: A Spatio-Temporal Analysis $\mathcal{C D}$

Table 2: Compound annual growth rate of area, production, yield of rice across different districts of Punjab (\% per annum)

\begin{tabular}{|c|c|c|c|c|c|c|c|c|c|}
\hline \multirow[t]{2}{*}{ Districts } & \multicolumn{3}{|c|}{ Period I (1994-04) } & \multicolumn{3}{|c|}{ Period II (2004-15) } & \multicolumn{3}{|c|}{ Period III (1994-15) } \\
\hline & A & $\mathbf{P}$ & $Y$ & $\mathbf{A}$ & $\mathbf{P}$ & $Y$ & $\mathbf{A}$ & $\mathbf{P}$ & $Y$ \\
\hline \multirow[t]{2}{*}{ Hoshiarpur } & 0.89 & 0.90 & -0.082 & $2.68^{* * *}$ & $5.12^{* * *}$ & $2.39^{* * *}$ & $1.41^{* * *}$ & $2.61^{* * *}$ & $1.18^{* * *}$ \\
\hline & $(0.007)$ & $(0.008)$ & $(0.003)$ & $(0.006)$ & $(0.01)$ & $(0.006)$ & $(0.002)$ & $(0.004)$ & $(0.002)$ \\
\hline \multirow[t]{2}{*}{ Gurdaspur } & 0.37 & $2.04^{* *}$ & $1.74^{* *}$ & 0.24 & $2.61^{*}$ & $0.30^{* *}$ & $0.46^{* * *}$ & $1.96^{* * *}$ & $1.56^{* * *}$ \\
\hline & $(0.002)$ & $(0.006)$ & $(0.006)$ & $(0.002)$ & $(0.013)$ & $(0.008)$ & $(0.002)$ & $(0.003)$ & $(0.003)$ \\
\hline \multirow[t]{2}{*}{ Rupnagar } & $3.89^{* * *}$ & $3.81^{* * *}$ & -0.26 & 0.052 & 0.14 & 0.091 & $3.49^{* * *}$ & $4.08^{* * *}$ & 0.06 \\
\hline & $(0.008)$ & $(0.007)$ & $(0.01)$ & $(0.002)$ & $(0.004)$ & $(0.002)$ & $(0.004)$ & $(0.004)$ & $(0.003)$ \\
\hline \multirow[t]{2}{*}{ S B S Nagar } & $1.10^{* *}$ & $1.36^{* *}$ & 0.21 & $1.49^{* * *}$ & $1.67^{*}$ & 0.17 & $1.81^{* * *}$ & $2.90^{* * *}$ & $1.07^{* * *}$ \\
\hline & $(0.004)$ & $(0.005)$ & $(0.004)$ & $(0.003)$ & $(0.007)$ & $(0.005)$ & $(0.001)$ & $(0.003)$ & $(0.002)$ \\
\hline \multirow[t]{2}{*}{ Amritsar } & $1.16^{* * *}$ & 0.34 & $-0.87^{*}$ & $0.58^{* * *}$ & 0.43 & -0.15 & $1.22^{* * *}$ & $1.107^{* * *}$ & -0.11 \\
\hline & $(0.002)$ & $(0.006)$ & $(0.004)$ & $(0.001)$ & $(0.004)$ & $(0.004)$ & $(0.001)$ & $(0.002)$ & $(0.002)$ \\
\hline \multirow[t]{2}{*}{ Kapurthala } & 0.55 & $3.06^{* * *}$ & $2.47^{* * *}$ & $1.08^{* * *}$ & $0.007^{* *}$ & -0.35 & $1.08^{* * *}$ & $2.51^{* * *}$ & $1.42^{* * *}$ \\
\hline & $(0.003)$ & $(0.007)$ & $(0.007)$ & $(0.002)$ & $(0.002)$ & $(0.002)$ & $(0.001)$ & $(0.002)$ & $(0.0024)$ \\
\hline \multirow[t]{2}{*}{ Jalandhar } & -0.04 & 0.68 & 0.83 & $1.54^{* * *}$ & $1.72^{* * *}$ & 0.18 & $1.48^{* * *}$ & $2.06^{* * *}$ & $0.64^{* * *}$ \\
\hline & $(0.01)$ & $(0.01)$ & $(0.005)$ & $(0.001)$ & $(0.004)$ & $(0.004)$ & $(0.003)$ & $(0.003)$ & $(0.001)$ \\
\hline \multirow[t]{2}{*}{ Ludhiana } & 0.18 & $2.88^{* *}$ & $2.70^{* * *}$ & $0.43^{* * *}$ & 0.1 & -0.33 & $0.59^{* * *}$ & $2.1^{* * *}$ & $1.5^{* * *}$ \\
\hline & $(0.002)$ & $(0.008)$ & $(0.007)$ & $(0.0007)$ & $(0.003)$ & $(0.003)$ & $(0.0006)$ & $(0.002)$ & $(0.0024)$ \\
\hline \multirow{2}{*}{$\begin{array}{l}\text { Fatehgarh } \\
\text { Sahib }\end{array}$} & 0.09 & $2.62^{* *}$ & $2.5^{* * *}$ & 0.16 & 0.29 & 0.13 & $0.32^{* * *}$ & $1.5^{* * *}$ & $1.18^{* * *}$ \\
\hline & $(0.002)$ & $(0.005)$ & $(0.005)$ & $(0.001)$ & $(0.004)$ & $(0.003)$ & $(0.0006)$ & $(0.002)$ & $(0.002)$ \\
\hline \multirow[t]{2}{*}{ Sangrur } & $1.24^{* *}$ & $3.18^{* * *}$ & $1.80^{* * *}$ & $0.51^{* * *}$ & $0.73^{* *}$ & 0.22 & $0.85^{* * *}$ & $2.45^{* * *}$ & $1.59^{* * *}$ \\
\hline & $(0.004)$ & $(0.005)$ & $(0.005)$ & $(0.0008)$ & $(0.003)$ & $(0.003)$ & $(0.001)$ & $(0.002)$ & $(0.002)$ \\
\hline \multirow[t]{2}{*}{ Patiala } & $0.68^{*}$ & $2.26^{* *}$ & $1.65^{* *}$ & 0.01 & 0.024 & 0.014 & $0.63^{* * *}$ & $1.77^{* * *}$ & $1.14^{* * *}$ \\
\hline & $(0.003)$ & $(0.007)$ & $(0.006)$ & $(0.0004)$ & $(0.0006)$ & $(0.0003)$ & $(0.0009)$ & $(0.002)$ & $(0.001)$ \\
\hline \multirow[t]{2}{*}{ Ferozepur } & 0.3 & 0.79 & 0.31 & $1.82^{* * *}$ & $1.30^{* * *}$ & -0.50 & $0.65^{* * *}$ & $1.39^{* * *}$ & $0.74^{* * *}$ \\
\hline & $(0.009)$ & $(0.007)$ & $(0.004)$ & $(0.02)$ & $(0.003)$ & $(0.003)$ & $(0.002)$ & $(0.002)$ & $(0.002)$ \\
\hline \multirow[t]{2}{*}{ Faridkot } & 2.1 & 1.41 & -0.50 & $2.33^{* * *}$ & $2.89^{* * *}$ & 0.56 & $2.56^{* *}$ & $3.53^{* * *}$ & $0.94^{* * *}$ \\
\hline & $(0.05)$ & $(0.05)$ & $(0.006)$ & $(0.002)$ & $(0.004)$ & $(0.004)$ & $(0.01)$ & $(0.01)$ & $(0.002)$ \\
\hline \multirow[t]{2}{*}{ Moga } & $5.52^{* * *}$ & $6.28^{* * *}$ & 0.50 & $0.69^{* * *}$ & $1.12^{* * *}$ & 0.43 & $3.02^{* * *}$ & $4.3^{* * *}$ & $1.30^{* * *}$ \\
\hline & $(0.01)$ & $(0.01)$ & $(0.0063)$ & $(0.001)$ & $(0.003)$ & $(0.003)$ & $(0.003)$ & $(0.004)$ & $(0.002)$ \\
\hline \multirow[t]{2}{*}{ Bathinda } & $11.86^{* * *}$ & $11.8^{* * *}$ & -0.10 & $2.11^{* * *}$ & $2.87^{* * *}$ & $0.75^{*}$ & $4.08^{* * *}$ & $5.31^{* * *}$ & $1.18^{* * *}$ \\
\hline & $(0.022)$ & $(0.019)$ & $(0.006)$ & $(0.006)$ & $(0.007)$ & $(0.004)$ & $(0.008)$ & $(0.007)$ & $(0.002)$ \\
\hline \multirow[t]{2}{*}{ Mansa } & $6.76^{* * *}$ & $6.44^{* * *}$ & -0.04 & $1.860^{* *}$ & 1.08 & $-0.77^{*}$ & $1.72^{* * *}$ & $2.68^{* * *}$ & $0.94^{* * *}$ \\
\hline & $(0.02)$ & $(0.016)$ & $(0.009)$ & $(0.006)$ & $(0.006)$ & $(0.003)$ & $(0.005)$ & $(0.005)$ & $(0.003)$ \\
\hline \multirow{2}{*}{ Muktsar } & $26.15^{* * *}$ & $25.88^{* * *}$ & 0.13 & $5.91^{* * *}$ & $5.55^{* * *}$ & -0.08 & $10.07^{* * *}$ & $10.88^{* * *}$ & $1.19^{* * *}$ \\
\hline & $(0.04)$ & $(0.034)$ & $(0.01)$ & $(0.009)$ & $(0.009)$ & $(0.006)$ & $(0.01)$ & $(0.013)$ & $(0.003)$ \\
\hline
\end{tabular}

${ }^{* * *}$ significant at $1 \%$ level, ** significant at $5 \%$ level, * significant at $10 \%$ level; Figures in the parenthesis are standard errors.

was insignificant. During period II (2004-15) area, production, yield of Fatehgarh sahib, Sangrur, Patiala remained stagnant. Ludhiana, Kapurthala, Amritsar showed same traits in case of area and production but their yield's growth rate turned out to be negative although all of them was insignificant. Jalandhar showed promising growth rate in area and production during period II but still its yield's growth was insignificant.
During period I growth rate area, production, yield of Ferozepur was stagnant, but growth rate of area and production of Faridkot showed promising increment during that period although CAGR of its yield turned out to be negative. During period II two districts showed entirely different picture, CAGR of yield of Ferozepur turned out to be negative where as CAGR of that parameter in case of Faridkot displayed positive growth. Moga, Bathinda, Mansa, 
Muktsar showed remarkable growth in area and production during Period I, but their growth rates of yield were stagnant at that time except Bathinda and Mansa, they showed negative growth rate. Tremendous increase of area in Period I for these districts might be because of the replacement of area with cotton due to failure of cotton. During Period II those districts' CAGR of area and production turned down but still showed positive growth rate this was because due to low productivity of rice some extent of cotton area was revived. In case of yield they showed same stagnant scenario except this time Mansa and Muktsar showed negative growth rate. In overall period (Period III) all the districts showed significant growth rate in terms of area and production. In terms of yield except Amritsar all the districts showed positive growth rate.

\section{Percentage share of area and production under rice in districts}

From Fig. 2 it can be observed that top seven districts with the highest area coverage under rice accounts almost $60 \%$ of the total rice growing area. In Punjab Sangrur had the highest share of total rice growing area among the districts $(13.28 \%)$, followed by Amritsar (12.55\%), Ferozepur (9.64\%), Patiala (9.15\%), Ludhiana (8.98\%), Gurdaspur (7.04\%), Moga (6.16\%).

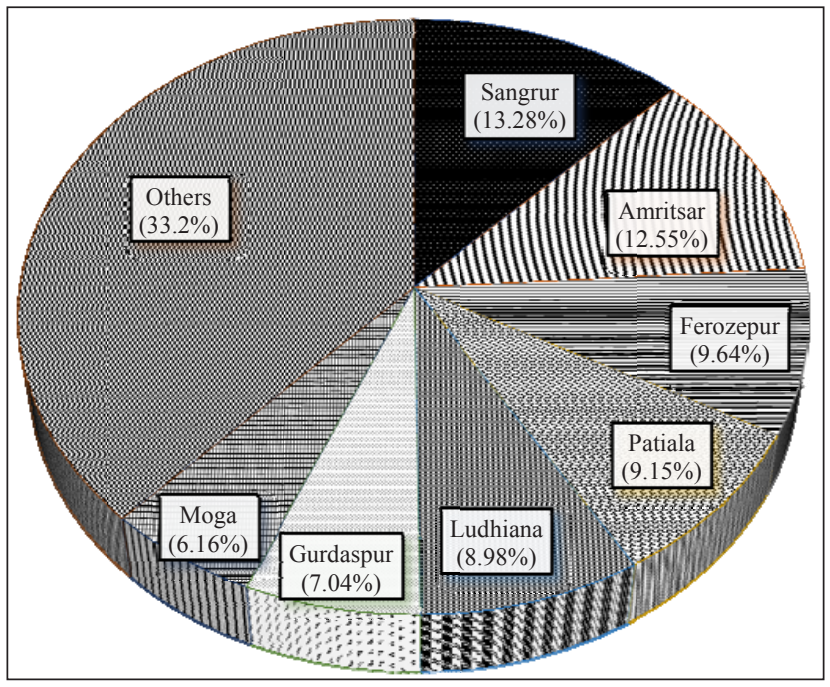

Fig. 2: Area under rice in important districts of Punjab

In terms of production it is clear that seven major rice producing districts also accounts for $60 \%$ of the total production. Again highest rice producing district was Sangrur (15.90\%), followed by Ludhiana
(10.15\%), Amritsar (9.75\%), Ferozepur (9.42\%), Patiala (8.95\%), Moga (7.18\%), Gurdaspur (6.20\%) (Fig. 3).

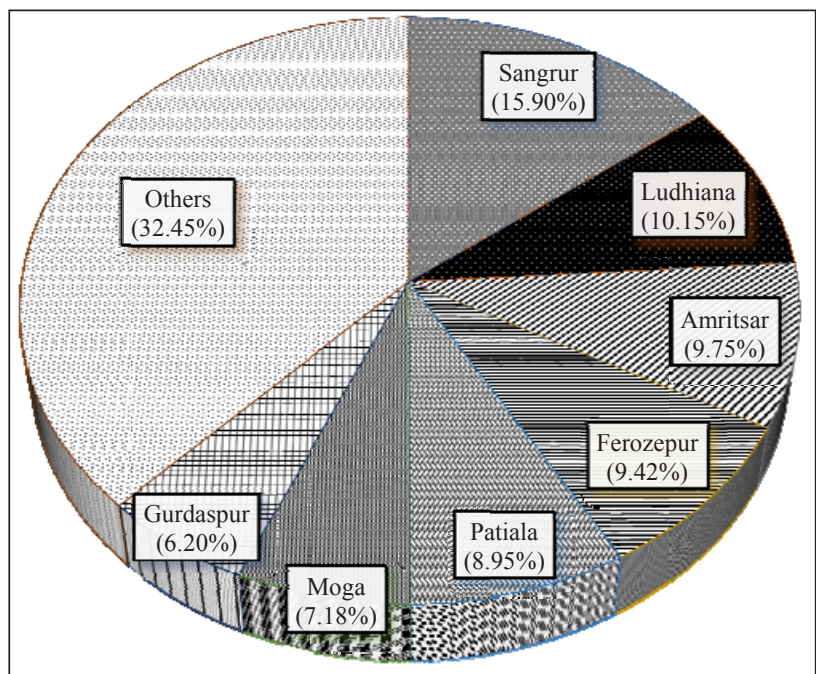

Fig 3: Production under rice in important districts of Punjab

\section{Factor affecting growth in area, production and yield of rice in Punjab}

The estimated parameters of factors affecting growth in area, production and yield of Punjab and West Bengal for the year 1994-16 are presented in Table 3.

Table 3: Factors affecting growth in area, production and yield of rice in Punjab from 1994-95 to 2015-16

\begin{tabular}{cccc}
\hline Variables & Area & Production & Yield \\
\hline Rainfall (R) & $\begin{array}{c}0.069^{* * *} \\
(4.85)\end{array}$ & $\begin{array}{c}-0.013 \\
(-0.10)\end{array}$ & $-0.088(-0.70)$ \\
& & & \\
Literacy Rate (LR) & $0.176^{* * *}$ & $0.274(0.77)$ & $0.067(0.19)$ \\
& $(4.37)$ & & \\
Cropping & $0.039(0.18)$ & $-1.40(-0.74)$ & $-1.48(-0.79)$ \\
Intensity (CI) & & & \\
Gross cultivable & $0.956^{* * *}$ & $1.55^{* * *}$ & $0.622^{*}(1.72)$ \\
area (GCA) & $(19.81)$ & $(3.62)$ & \\
Gross irrigated & $-0.16(-1.13)$ & $0.637(0.51)$ & $0.822(0.67)$ \\
area (GIA) & & & \\
Fertilizer & $-0.04^{* *}(-2.04)$ & $0.185(1.06)$ & $0.233^{*}(1.76)$ \\
consumption (FC) & & & \\
Constant & $8.08^{* * *}(6.76)$ & $16.10^{*}(1.72)$ & $15.29^{*}(1.72)$
\end{tabular}




$\begin{array}{cccc}\text { F-stat } & 694.5 & 25.53 & 4.87 \\ \text { R-squared } & 0.996 & 0.911 & 0.661 \\ \text { Adj. R-squared } & 0.994 & 0.875 & 0.526 \\ \begin{array}{c}\text { No. of } \\ \text { observations }\end{array} & 22 & 22 & 22\end{array}$

Source: India stat.com 2016; Note: ${ }^{* * *}$ significant at $1 \%$ level, ** significant at $5 \%$ level, * significant at $10 \%$ level; The figures within the parentheses are the value of $t$-statistics.

The results regarding the effect of factors on growth of area under cultivation are presented in column 2 in case of Punjab. The coefficient of factors like rainfall, gross cultivable area were positive and significant but in case of fertilizer the coefficient is negative and significant. This might be due to increase in use of fertilizer same level of production could be maintained by using less amount of land than before and land utilization was shifted to other crops. In case of production only the coefficient of gross cultivable area were positive and significant growth but in case of yield both gross cultivable area and fertilizer use were positive and significant. Pattanaik and Mohanty (2016) had found similar effect of these variables on growth of major crop groups in Odisha agriculture.

\section{CONCLUSION}

During 1994-04 the tremendous increase in rice production of Punjab (3.33 percent) was due to increase in area (2.12 percent) at that time. The similar pattern was followed in period II. But in period-III (1994-16) the growth of production (2.36 percent) was due to both growth in the area (1.29 percent) and yield (1.06 percent). Both the area under HYV and irrigation increased notably during period I, 4.12 and 2.33 percent respectively.

In Punjab Sangrur, Ludhiana and Amritsar are three major rice producing districts, during period I (1994-04) except Ludhiana rice area of both Sangrur and Amritsar increased significantly. In terms of production except Amritsar both production of Ludhiana and Sangrur increased significantly. In terms of yield only Amritsar showed declining trend. Muktsar, Mansa, Bathinda, Moga showed tremendous increase in area and production but their yield did not show any significant growth rate. During period II (2004-15) area, production of all three major rice producing districts displayed stagnant growth but in terms of yield except Sangrur both Ludhiana and Amritsar showed declining growth. Mansa Bathinda, Moga did not show that much growth rate in area and production as in previous period. In overall period (1994-16) all the districts showed significant growth in terms of area and production but in terms of yield except Amritsar all the districts showed significant growth rate.

In Punjab top seven states with highest area coverage under rice accounts almost $60 \%$ of the total rice growing area. Among the state Sangrur had the highest share of total rice growing area of the states (13.28\%), followed by Amritsar (12.55\%), Ferozepur (9.64\%), Patiala (9.15\%), Ludhiana $(8.98 \%)$, Gurdaspur (7.04\%), Moga (6.16\%). In terms of production it is clear that seven major rice producing districts also accounts for $60 \%$ of the total production. Again highest rice producing district was Sangrur (15.90\%), followed by Ludhiana (10.15\%), Amritsar (9.75\%), Ferozepur (9.42\%), Patiala (8.95\%), Moga (7.18\%), Gurdaspur (6.20\%).

The coefficient of factors like rainfall, gross cultivable area were positive and significant but in case of fertilizer the coefficient is negative and significant for the growth of area under rice cultivation. In case of production only the coefficient of gross cultivable area were positive and significant growth but in case of yield both gross cultivable area and fertilizer use were positive and significant.

\section{REFERENCES}

Anonymous. 2016. Area and production under rice in India Retrieved from www.indiastat.com.

Anonymous. 2016. Area and production under rice in Punjab Retrieved from www.indiastat.com.

Anonymus. 2015. Statistical Abstract of Punjab, Economics Adviser to Government, Punjab.

Bhalla, G.S. and Singh, G. 2009. Economic liberaliation and Indian agriculture: A state-wise analysis. Econ. Pol. Weekly, 54(2): 34-44.

Bhattacharya, S. and Bhattacharya, M. 2007. Agarian impasse in West Bengal in the liberalisation era. Econ. Pol. Weekly, 42(52): 65-71.

Dutta, S. 2012. Green Revolution Revisited: The Contemporary Agrarian Situation in Punjab, India. Social Change, 42(2): 229-247. 
CD Das and Kumar

Joshi, P.K., Singh, P.B. and Nicholas, M. 2006. Sources of Agricultural Growth in India: Role of Diversification towards High Value Crops, MTID Discussion Paper No. 98. International Food Policy Research Institute, Washington, D.C.

Pattanaik, P. and Mohanty, S. 2016. Growth Performance of Major Crop Groups in Odisha Agriculture: A Spatiotemporal Analysis. Agri. Econ. Res. Rev., 29(2): 225-237.

Paltasingh, K.R. and Goyari, P. 2013. Analysing growth and instability in subsistence agriculture of Odisha: Evidence from major crops. Agri. Econ. Res. Rev., 26: 67-78.

Rena, Ravinder. 2004. “Green Revolution: Indian Agricultural Experience - A Paradigm for Eritrea", New Jersey, USA: Eritrean Studies Rev., 4(1): 103-130.
Singh, K.M., Chaudhari, J.N. and Singh, R.K.P. 1993. An analysis of compound Growth Rates and Factors Affecting Area, Production and Productivity of Gram in Bihar. Agri. Situ. Ind., 47: 841-46.

Subrahmanyam, S. and Satya Sekhar, P. 2003. Agricultural growth: Pattern and prospects. Econ. Pol. Weekly, 38(12/13): 1202-1211.

Vakulabharanam, V. 2004. Agricultural growth and irrigation in Telangana: A review of evidence. Econ. Pol. Weekly, 39(13): 1421-1426. 